\title{
Leukotriene receptor antagonists in the treatment of asthma: Implications for eosinophilic inflammation
}

\author{
Redwan Moqbel PhD FRCPath \\ Pulmonary Research Group, University of Alberta, Edmonton, Alberta
}

$\mathbf{R}$ Moqbel. Leukotriene receptor antagonists in the treatment of asthma: Implications for eosinophilic inflammation. Can Respir J 1999;6(5):453-457.

Recent advances in the treatment and management of asthma have suggested that leukotriene (LT) receptor antagonists may be very beneficial as a second generation therapy with steroid-sparing properties and negligible side effects. These agents have shown interesting effects on peripheral blood and sputum eosinophils. A major contributor to the damage in the airway of asthmatic patients is the eosinophil, which, upon activation, releases a battery of granule-associated cytotoxic, cationic proteins, including the major basic protein and eosinophil peroxidase, and membrane-derived de novosynthesized bioactive lipid mediators, including $\mathrm{LTC}_{4}$, $\mathrm{LTD}_{4}$ and LTE 4 , as well as platelet activating factor. These products have deleterious effects on the airway tissue including mucosal and smooth muscle layers. Accumulating evidence suggests that these agents may also influence the accumulation and maintenance of eosinophilic responses at the site of inflammation. This article reviews the possible anti-inflammatory mode of action of these therapies. It also discusses where there may be a gap in the knowledge regarding the potential direct and indirect effects of LT modifiers on eosinophil function and recruitment.

Key Words: Asthma; Eosinophil; Inflammation; Leukotriene

\section{Les antagonistes des récepteurs des leucotriènes dans le traitement de l'asthme : implications pour l'inflammation éosinophile}

RÉSUMÉ : Les progrès récents réalisés dans le traitement et la prise en charge de l'asthme laissent croire que les antagonistes des récepteurs des leucotriènes (LT) peuvent être très bénéfiques comme traitement de deuxième génération avec des propriétés permettant de réduire les stéroïdes et des effets secondaires négligeables. Ces agents ont démontré des effets intéressants sur les éosinophiles contenus dans l'expectoration et dans le sang périphérique. Un des principaux responsables des dommages causés aux voies aériennes des patients asthmatiques est l'éosinophile, qui, lorsqu'il est activé, libère une gamme de protéines cationiques, cytotoxiques associées aux granules de l'éosinophile, incluant la protéine majeure basique et la péroxidase de l'éosinophile, et des médiateurs lipidiques bioactifs néoformés et dérivés de la membrane, comprenant les LTC4, LTD4 et LTE4 de même que le PAF. Ces produits ont des effets délétères sur les tissus des voies aériennes y compris sur les couches des muqueuses et du muscle lisse. Un nombre grandissant de preuves permettent de croire que ces agents pourraient aussi influer sur l'accumulation et le maintien des réponses éosinophiles au site de l'inflammation. Le présent article passe en revue le mode d'action antiinflammatoire potentielle de ces traitements. Il discute également des endroits où il peut y avoir des failles dans les connaissances concernant les effets directs et indirects potentiels des modificateurs des LT sur la fonction et le recrutement éosinophile. 
A sthma is a heterogeneous and complex condition afflicting a wide range of population of varying age and sex. It is now generally recognized that the disease is caused mainly by inflammation in the airways (Figure 1). This results in reversible airway obstruction and bronchial hyperresponsiveness, which at times can be fatal. Until recently, the treatment of asthma was confined to symptom relieving (beta2-agonists) and/or preventive therapy, ie, corticosteroids (inhaled and/or systemic).

Activated T cells and eosinophils are thought to play a major role in asthma, and the numbers of these cells correlate broadly with disease severity (1). Mucosal damage in chronic asthma is believed to be the consequence of cytotoxic and proinflammatory mediator release from activated eosinophils $(2,3)$. These include cytotoxic granule proteins (major basic protein, eosinophil cationic protein, eosinophil peroxidase, and eosinophil-derived neurotoxin) together with phospholipidderived, pharmacologically active mediators. Cytokines derived from $\mathrm{T}$ helper (Th) 2-type cells, particularly interleukin (IL)-3, IL-5 and granulocyte-macrophage colony-stimulating factor (GM-CSF), are thought to regulate eosinophil activation and promote their survival $(4,5)$. IL-5 is an obligatory terminal differentiator of eosinophil precursors (6).

\section{SULPHIDOPEPTIDE (CYSTEINYL) LEUKOTRIENES}

Eosinophils are a rich source of the sulphidopeptide leukotrienes (2). These are de novo-synthesized lipid mediators derived from arachidonic acid (AA) by the action of phospholipase $\mathrm{A}_{2}$ (PLA2) (7). AA is found in association with the plasma membrane as well as cytoplasmic lipid bodies in these cells (8), and is metabolized through one of two pathways, cyclo-oxygenase and lipoxygenase (9). The former leads to the generation of prostaglandins, thromboxanes and prostacyclins. The second pathway, via the 5-lipoxygenase (5-LO) enzyme acting in concert with a cofactor, 5-LO activating protein (FLAP), generates leukotrienes (LTs), including $\mathrm{LTB}_{4}, \mathrm{LTC}_{4}, \mathrm{LTD}_{4}$ and $\mathrm{LTE}_{4}$ (10).

The 5-LO enzyme cleaves AA to form 5-hydroperoxy eicosatetranoic acid [5-HPETE] and the subsequent synthesis of an unstable intermediate epoxide ( $\left.\mathrm{LTA}_{4}\right)$, which is translocated to the perinuclear membrane (11). In turn, LTA4 rapidly converts to either $\mathrm{LTB}_{4}$ (via the action of $\mathrm{LTA}_{4}$ hydrolase), or the cysteinyl LT LTC4 (5S-hydroxy-6R,S-glutathionyl7,9,-trans-11,14-cis-eicosatetraenoic acid) through the action of $\mathrm{LTC}_{4}$ synthase in the nuclear membrane. This is achieved by adding the tripeptide glutathione onto $\mathrm{LTA}_{4}(7)$.

Eosinophils produce negligible amounts $\left(6 \mathrm{ng} / 10^{6}\right.$ cells $)$ of $\mathrm{LTB}_{4}$ (5S-12R-dihydroxy-6,14-cis-8,10-trans-eicosatetraenoic acid) (12) compared with up to $200 \mathrm{ng} / 10^{6}$ cells from neutrophils. $\mathrm{LTB}_{4}$ is a chemotactic, priming and activating factor for leukocytes, including neutrophils (13). In contrast, human eosinophils generate relatively large quantities of $\mathrm{LTC}_{4}$ (up to $70 \mathrm{ng} / 10^{6}$ cells) after stimulation with the calcium ionophore A23187 (14). In general, eosinophils obtained from asthmatic subjects appear to produce more $\mathrm{LTC}_{4}$ than those from normal healthy donors $(15,16)$. Furthermore, co-culture of eosinophils with endothelial cells (17), or exogenous addition of cytokines, eg, IL-3, IL-5, GM-CSF and tumour necrosis factor-alpha (TNF $\alpha$ ) was shown to result in the upregulation of ionophore-induced release of $\mathrm{LTC}_{4}$ (18-20).

When $\mathrm{LTC}_{4}$ is formed, it is transported actively out of the cell. $\mathrm{LTD}_{4}$ and $\mathrm{LTE}_{4}$ are produced from $\mathrm{LTC}_{4}$ by the removal of glutamic acid (via the action of -glutamyl transpeptidase) and glycine (via the action of dipeptidase), respectively $(7,9)$. $\mathrm{LTC}_{4}, \mathrm{D}_{4}$ and $\mathrm{E}_{4}$ collectively form the activity previously recognized as 'slow reacting substance of anaphylaxis', due to their prolonged in time spasmogenic effects on smooth muscles. Although $\mathrm{LTD}_{4}$ and $\mathrm{LTE}_{4}$ are rapidly degraded in the body through oxidative metabolism, small amounts of $\mathrm{LTE}_{4}$ can be measured in the urine (21). Interestingly, in humans, the leukotriene pathway, via 5-LO, is observed only in myeloid cells, ie, mast cells, basophils, neutrophils, eosinophils and alveolar macrophages (22). Recent studies have suggested that cysteinyl LTs may also have selective eosinophilotactic activity $(23,24)$.

\section{LT RECEPTORS}

Two receptors for cysteinyl LTs have been identified on smooth muscle cells, namely, Cys-LT1 and Cys-LT2. CysLT1 is now recognized as the probable regulating receptor for bronchial smooth muscle contraction and, thus, may be directly relevant to asthma treatment (25). Cys-LT2, on the other hand, appears to be mainly involved in pulmonary vein contraction (26). In addition to $\mathrm{LTD}_{4}$, both $\mathrm{LTC}_{4}$ and $\mathrm{LTE}_{4}$ bind to Cys-LT1, although LTE4 exhibits a greatly reduced binding capacity (25). There is, however, no evidence available in the literature to suggest that eosinophils express either of these two receptors for LTs. One exception is the observation that HL-60 cells, which were differentiated into eosinophils, in vitro, expressed a very low affinity $\mathrm{LTD}_{4}$ receptor (Kd $41.91 \mathrm{nM}$ ) (27). However, these cells may not reflect fully all the properties and the biological profile of circulating mature eosinophils.

\section{EVIDENCE FOR A BIOLOGICAL ROLE FOR LTS IN ASTHMA}

Evidence has accumulated to suggest that, in vivo, LTs are among the most potent constrictors of airway smooth muscle and are, thus, major players in the complex picture of asthmatic inflammation. A substantial amount of the published literature shows that LTs are critical elements in the development, progression and chronicity of the inflammatory response associated with various clinical presentations of asthma (28-30). For instance, both $\mathrm{LTC}_{4}$ and $\mathrm{LTD}_{4}$, when inhaled, are an order of magnitude greater in pharmacological potency than histamine in inducing airflow obstruction in normal subjects, and their effects lasted longer. In these studies, asthmatic airways appeared to be more sensitive (100 to 1000 times) to inhaled cysteinyl LTs than those of nonasthmatic subjects. These patients also demonstrated increased bronchial hyperresponsiveness to methacholine or histamine following inhalation of $\mathrm{LTC}_{4}$ and $\mathrm{LTD}_{4}(31)$. 


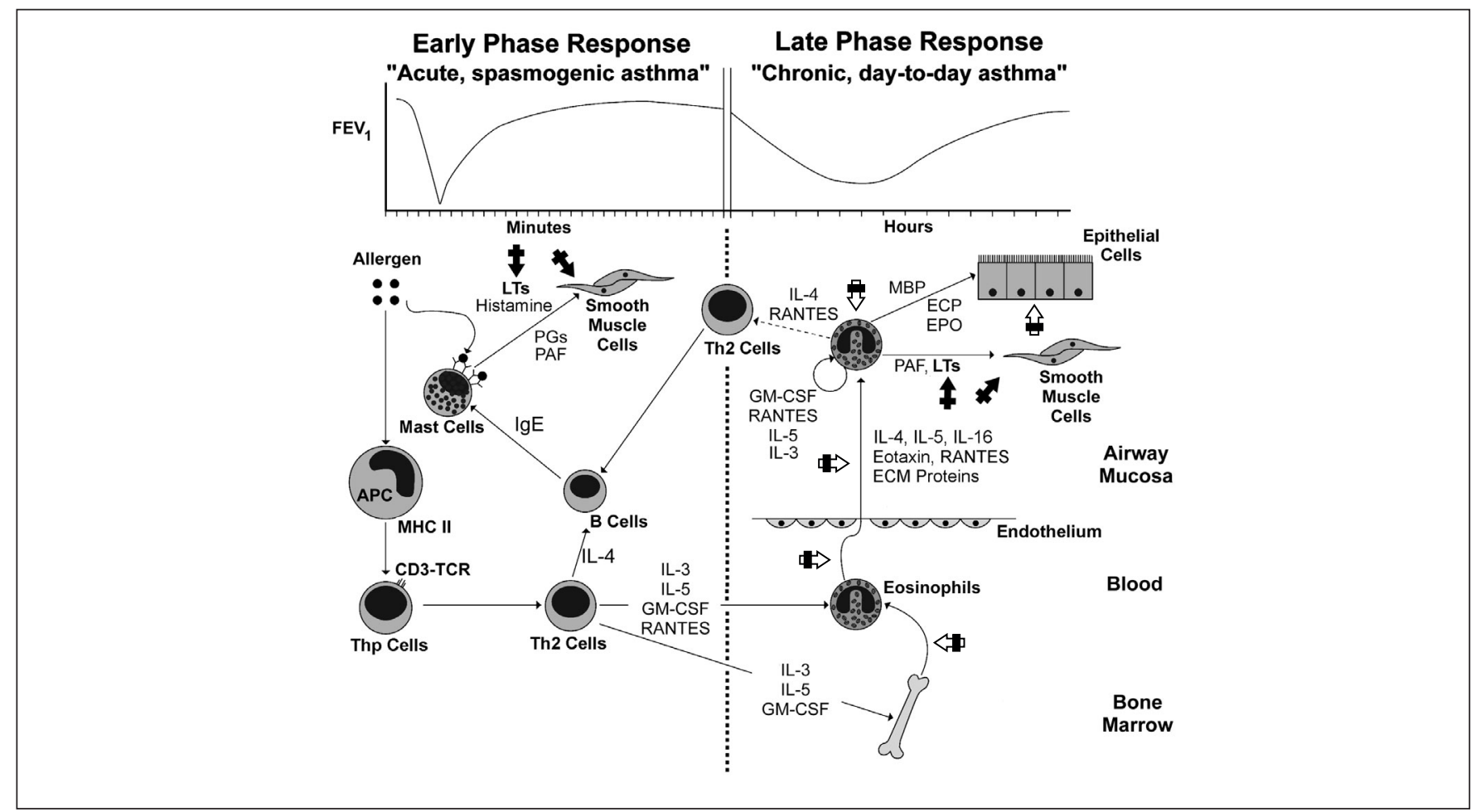

Figure 1) A schematic representation of the current understanding of putative immune and inflammatory mechanisms regulating the early late phase asthmatic response. Cytokines and chemokines have the potential to exert regulatory influences on the inflammatory cascade involving the eosinophil. Leukotriene (LTs) modifiers are thought to modulate the response $\boldsymbol{\omega})$ at the level of the smooth muscle cells. Little is known about the potential of these agents to influence eosinophil or epithelial cell responses ( $\rightarrow$ ). APC Antigen presenting cells; ECM Extracellular matrix proteins; ECP Eosinophil cationic protein; EPO Eosinophil peroxidase; FEV $V_{1}$ Forced expiratory volume in 1 s; GM-CSF Granulocyte-macrophage colony-stimulating factor; Ig Immunoglobulin; IL Interleukin; MBP Major basic protein; MHC Major histocompatibility complex; PAF Platelet activiating factor; PG Prostaglandin; Th T helper cells; Thp T helper precursor; TCR T cell receptor

\section{LT MODIFIERS}

The potential contribution of the sulphidopeptide LTs in bronchoconstriction has been identified by recent developments in the field of LT-modifying therapies $(30,32)$. Earlier studies and trials with LT inhibitors and receptor antagonists were disappointing, mainly due to toxicity, lack of specificity and limited potency of the agents (33).

Two new strategies aimed at blocking the effects of the LT pathway have recently gained rapid momentum and provided hope for better and more efficient treatment for asthma. The first area relates to the development of LT synthesis inhibitors, such as zileuton and BAYx1005. These were shown to produce significant reductions in LT generation levels, including both LTB4 and the cysteinyl LTs $(34,35)$. Zileuton inhibits the 5-LO and, thus, prevents the synthesis of LTA4 (34). In contrast, BAYX1005 is an antagonist of FLAP, which prevents the translocation of 5-LO and blocks the formation of LTA4 (35). This area of FLAP inhibition is currently under intensive development because it will determine the role of other products of 5-LO metabolic pathway in asthmatic inflammation.

More recently, second generation $\mathrm{LTD}_{4}$ receptor antagonists have been introduced. These new agents have the potential to inhibit the biological activities of $\mathrm{LTD}_{4}$ and the other members of the cysteinyl LT family by competing for their receptors on smooth muscle cells (36). These include monte- lukast (Singulair [Merck Frosst Canada Inc, Kirkland, Quebec]), zafirlukast (Accolate [Zeneca Pharma Inc, Mississauga, Ontario]), and pranlukast (Ultair, SmithKline Beecham, United Kingdom), which, when used in inhalation challenge studies, in vivo, have demonstrated a greater potency in blocking LT effects and a better safety record $(37-40)$.

\section{LT MODIFIERS AND THE EOSINOPHIL IN ASTHMA}

The clinical effects of LT receptor antagonists (including montelukast and zafirlukast) on dampening the pathophysiological sequelae of inflammation in asthma have been amply reviewed previously (37-41). These reports show clearly that these agents have significant efficacy in controlling asthma symptoms in a large percentage of patients. The present paper concentrates on the as yet unanswered question of whether LT receptor antagonists are anti-inflammatory drugs, potent bronchodilators or both. In particular, the issue of the biological relevance and efficacy of LT receptor antagonists from the perspective of their effect on the eosinophil is addressed. As stated earlier, the latter is a highly relevant inflammatory cell type in asthmatic airway mucosal tissue (Figure 1) (3).

Recent observations have shown that both montelukast and zafirlukast suppress eosinophil numbers in the peripheral 
blood and airways $(42,43)$. Using hypertonic saline-induced sputum as an indicator of cellular infiltration associated with asthmatic inflammation, researchers demonstrated significant reductions in the numbers of sputum eosinophils following treatment with montelukast (44). A consequence of such studies has been to provide further fuel to the hypothesis, and possibly a subtle conclusion, that cysteinyl LTs possess eosinophilotactic properties $(23,24,42)$.

There are many areas that have not yet been studied in relation to the effect of LT receptor antagonists on eosinophil biology and its natural history in asthma (Figure 1). In order to reach a better conclusion about the biological effects of leukotriene modifiers on eosinophils in asthma, further supportive evidence is needed. LT activity blockers, such as montelukast and zafirlukast, may indeed influence the eosinophilic response but through various and potentially complex paths.

The first missing evidence relates to the potential effects of LT modifiers on bone marrow or in situ eosinophil progenitors and committed precursors (45). It is possible, if not likely, that these drugs exert anti-inflammatory properties at the level of the bone marrow. Studies aimed at examining the mode of action of these agents in cultures of CD $34^{+}$cells obtained either from bone marrow or other hemopoietic tissue (including umbilical cord blood) in vitro (46) are needed. In addition, the effects of these agents on bone marrow levels of eosinophil-sensitive chemokines (such as RANTES and eotaxin) require investigation. This would help determine whether there is a potential blocking action of these agents on the proximal arm controlling the egress of eosinophils from hemopoietic sites (Figure 1).

Second, there is a strong likelihood that the pharmacological effects of montelukast on eosinophil numbers may be an indirect one. I prefer this hypothesis in favour of the notion that cysteinyl LTs exhibit eosinophilotactic properties. Previous and carefully conducted studies concluded that $\mathrm{LTC}_{4}, \mathrm{D}_{4}$ and $\mathrm{E}_{4}$ had negligible chemotactic activity for eosinophils $(13,47)$. Furthermore, these sulphidopeptide LTs showed no upregulatory effects on eosinophil effector function (including cytotoxicity), at least compared with $\mathrm{LTB}_{4}$ (48). Thus, it seems more likely that this indirect effect on eosinophil recruitment to the airway, as shown by reduced eosinophil counts in sputum, may be mediated via LT receptor-mediated effects on epithelial cells. This may in turn influence the synthesis, storage and release of eosinophilotactic chemokines, such as RANTES and eotaxin $(49,50)$, both of which have been shown to be present in the bronchial tissue in asthma $(51,52)$. In addition to chemokines, epithelial cell-induced eosinophil chemoattraction may also be influenced by cytokines, particularly IL-16 (Figure 1). IL-16, a potent T-cell and eosinophilotactic cytokine and a major product of bronchial epithelial cells, as well as other inflammatory cells including eosinophils, uses CD4 receptors on eosinophils in its chemotactic activity $(53,54)$. IL-16 expression has recently been shown to be a pathological feature of human bronchial asthma (55).
Third, it seems that we know very little about the influence of montelukast treatment on IL-5 bioactivity both locally and systemically. This cytokine is a critical factor in eosinophil terminal differentiation and, together with IL-3 and GM-CSF, prolongs eosinophil survival in the tissue. However, data from a recent study (42) have suggested that IL-5 levels may be reduced in the sputum. This may provide further support to the notion that LT modifiers may exert their influence on the eosinophilic response via IL-5 protein synthesis and turnover in asthmatic airways (Figure 1).

Finally, montelukast-induced reduction in the number of peripheral blood and airway eosinophils may be due to the ability of this agent to induce eosinophil death, particularly apoptosis. Furthermore, whether engaging putative Cys-LT1 on eosinophils may be important in prolonging the survival of these cells is another worthwhile area of investigation.

\section{CONCLUSIONS}

The eosinophil may be an important target for the pharmacological activities of LT receptor antagonists. It is likely that the anti-asthma efficacy of these antagonists may relate partly to their direct and/or indirect anti-eosinophilic properties. However, much remains to be unveiled in regard to their anti-eosinophilic effects. Our aim should be to obtain a better understanding of the mode of action of leukotriene modifiers with a view to clarify their potential 'anti-inflammatory' and "steroid-sparing" properties. Such data should contribute to a more efficacious administration of these therapies in asthma.

ACKNOWLEDGEMENTS: The author wishes to thank Dr Paige Lacy for ongoing discussions and helpful comments on the manuscript. Redwan Moqbel is an Alberta Heritage Senior Medical Scholar.

\section{REFERENCES}

1. Corrigan CJ, Kay AB. T cells and eosinophils in the pathogenesis of asthma. Immunol Today 1992;13:501-7.

2. Gleich GJ, Adolphson CR. The eosinophil leukocyte: structure and function. Adv Immunol 1986;39:177-253.

3. Wardlaw AJ, Moqbel R, Kay AB. Eosinophils: biology and role in disease. Adv Immunol 1995;60:151-266.

4. Lopez AF, Sanderson CJ, Gamble JR, Campbell HD, Young IG, Vadas MA. Recombinant interleukin 5 is a selective activator of human eosinophil function. J Exp Med 1988;167:219-24.

5. Rothenberg ME, Owen WF Jr, Silberstein DS, et al. Human eosinophils have prolonged survival, enhanced functional properties, and become hypodense when exposed to human interleukin-3. J Clin Invest 1988;81:1986-92.

6. Clutterbuck EJ, Hirst EMA, Sanderson CJ. Human interleukin-5 regulates the production of eosinophils in human bone marrow cultures: comparison and interaction with IL-1, IL-3, IL-6, and GM-CSF. Blood 1989;73:1504-12.

7. Samuelsson B, Dahlen SE, Lindgren JA, Rouzer CA, Serhan CN. Leukotrienes and lipoxins: structure, biosynthesis, and biological effects. Science 1987;237:1171-6.

8. Bozza PT, Yu W, Penrose JF, Morgan ES, Dvorak AM, Weller PF. Eosinophil lipid bodies: specific, inducible intracellular sites for enhanced eicosanoid formation. J Exp Med 1997;186:909-20.

9. Henderson WR Jr. Eicosanoids and lung inflammation. Am Rev Respir Dis 1987;135:1176-85.

10. Mancini JA, Abramovitz M, Cox ME, et al. 5-Lipoxygenase activating protein is an arachidonate binding protein. FEBS Lett 1993;31:277-81.

11. Woods JW, Evans JF, Ethier D, et al. 5-Lipoxygenase and 
5-lipoxygenase-activating protein are localized in the nuclear envelope of activated human leukocytes. J Exp Med 1993;178:1935-46.

12. Jorg A, Henderson WR, Murphy RC, Klebanoff SJ. Leukotriene generation by eosinophils. J Exp Med 1982;155:390-402.

13. Nagy L, Lee TH, Goetzl EJ, Pickett WC, Kay AB. Complement receptor enhancement and chemotaxis of human neutrophils and eosinophils by leukotrienes and other lipoxygenase products. Clin Exp Immunol 1982;47:541-7.

14. Weller PF, Lee CN, Foster DW, Corey EJ, Austen KF, Lewis RA. Generation and metabolism of 5-lipoxygenase pathway leukotrienes by human eosinophils: predominant production of leukotriene $\mathrm{C}_{4}$. Proc Natl Acad Sci USA 1983;80:7626-30.

15. Aizawa T, Tamura G, Ohtsu H, Takashima T. Eosinophil and neutrophil production of leukotriene $\mathrm{C}_{4}$ and $\mathrm{B}_{4}$ : comparison of cells from asthmatic subjects and healthy donors. Ann Allergy 1990;64:287-92.

16. Kohi F, Miyagawa H, Agrawal DK, Bewtra AK, Townley RG. Generation of leukotriene $\mathrm{B}_{4}$ and $\mathrm{C}_{4}$ from granulocytes of normal controls, allergic rhinitis and healthy donors. Ann Allergy 1990;65:228-32.

17. Rothenberg ME, Owen WF Jr, Silberstein DS, Soberman RJ, Austen KF, Stevens RL. Eosinophils co-cultured with endothelial cells have increased survival and functional properties. Science 1987;237:645-7.

18. Rothenberg ME, Owen WF Jr, Silberstein DS, et al. Human eosinophils have prolonged survival, enhanced functional properties, and become hypodense when exposed to human interleukin-3. J Clin Invest 1988:81:1986-92.

19. Rothenberg ME, Petersen J, Stevens RL, et al. IL-5-dependent conversion of normodense human eosinophils to the hypodense phenotype uses $3 \mathrm{~T} 3$ fibroblasts for enhanced viability, accelerated hypodensity, and sustained antibody-dependent cytotoxicity. J Immunol 1989;143:2311-6.

20. Roubin R, Elsas PP, Fiers W, Dessein AJ. Recombinant human tumour necrosis factor (TNF) 2 enhances leukotriene biosynthesis in neutrophils and eosinophils stimulated with the $\mathrm{Ca}^{2+}$ ionophore A23187. Clin Exp Immunol 1987;70:484-90.

21. Drazen JM, O'Brien J, Sparrow D, Weiss ST, Martins MA, Israel E, Fanta $\mathrm{CH}$. Recovery of leukotriene $\mathrm{E}_{4}$ from the urine of patients with airway obstruction. Am Rev Respir Dis 1992;146:104-8.

22. Lewis RA, Austen KF, Soberman RJ. Leukotrienes and other products of the 5-lipoxygenase pathway: biochemistry and relationship to pathobiology in human diseases. N Engl J Med 1990;323:645-55.

23. Hay DWP, Torphy TJ, Undem BJ. Cysteinyl leukotrienes in asthma: old mediators up to new tricks. Trends Pharmacol Sci 1995;16:304-09.

24. Laitinen LA, Laitinen A, Haahtela T, Vilkka V, Spur BW, Lee TH. Leukotriene $\mathrm{E}_{4}$ and granulocytic infiltration into asthmatic airways. Lancet 1993;341:989-90.

25. Coleman RA, Eglen RM, Jones RL, et al. Prostanoid and leukotriene receptors: a progress report from the IUPHAR working parties on classification and nomenclature. Adv Prostaglandins Thromboxane Leukotriene Res 1995;23:283-5.

26. Labat C, Ortiz JL, Norel X, et al. A second cysteinyl leukotriene receptor in human lung. J Pharmacol Exp Ther 1992;263:800-5

27. Patry C, Muller E, Laporte J, Rola-Pleszczynski M, Sirois P, de Brum-Fernandes AJ. Leukotriene receptors in HL-60 cells differentiated into eosinophils, monocytes and neutrophils. Prostaglandin Leukot Essent Fatty Acids 1996;54:361-70.

28. Wenzel SE. Arachidonic acid metabolites: mediators of inflammation in asthma. Pharmacotherapy 1997;17(Suppl 1 Pt 2):3S-12S.

29. O'Byrne PM, Israel E, Drazen JM. Antileukotrienes in treatment of asthma. Ann Intern Med 1997;127:472-80.

30. Busse WW. The role of leukotrienes in asthma and allergic rhinitis. Clin Exp Allergy 1996;26:868-79.

31. O'Hickey SP, Hawksworth RJ, Fong CY, Arm JP, Spur BN, Lee TH. Leukotrienes $\mathrm{C}_{4}, \mathrm{D}_{4}$, and $\mathrm{E}_{4}$ enhance histamine responsiveness in asthmatic airways. Am Rev Respir Dis 1991;144:1053-7.

32. Sorkness CA. The use of 5-lipoxygenase inhibitors and leukotriene receptor antagonists in the treatment of chronic asthma. Pharmacotherapy 1997;17(Supplement \#):50S-4S.

33. Spector SL. Leukotriene inhibitors and antagonists in asthma. Ann Allergy Asthma Immunol 1995;75:463-70,473.
34. Dahlen b, Kumlin M, Ihre E, Zetterstrom M, Dahlen S-E. Inhibition of allergen-induced airway obstruction and leukotriene generation in atopic asthmatic subjects by the leukotriene biosynthesis inhibitor BAYx 1005. Thorax 1997:52:342-7.

35. McGill KA, Busse WW. Zileuton. Lancet 1996;348:519-24.

36. Goerenne I, Norel X, Brink C. Cysteinyl leukotriene receptors in the human lung: what's new? Trends Pharmacolog Sci 1996;17:342-5.

37. Leff JA, Busse WW, Pearlman D, et al. Montelukast, a leukotriene-receptor antagonist, for the treatment of mild asthma and exercise-induced bronchoconstriction. N Engl J Med 1998;339:147-52.

38. Noonan MJ, Chervinsky P, Brandon M, et al. Montelukast, a potent leukotriene receptor antagonist, causes dose-related improvements in chronic asthma. Montelukast Asthma Study Group. Eur Respir J 1998;11:1232-9.

39. Adkins JC, Brogden RN. Zafirlukast. A review of its pharmacology and therapeutic potential in the management of asthma. Drugs 1998;55:121-44.

40. Barnes NC, de Jong B, Miyamoto T. Worldwide clinical experience with the first marketed leukotriene receptor antagonist. Chest 1997;111(Suppl G):52S-60S.

41. O'Byrne PM. Asthma treatment: anti-leukotriene drugs. Can Respir J 1998;5(Suppl A):64A-70A.

42. Reiss TF, Chervinsky P, Dockhorn RJ, Shingo S, Seidenberg B, Edwards TB. Montelukast, a once-daily leukotriene receptor antagonist, in the treatment of chronic asthma: a multicenter, randomized, double-blind trial. Montelukast Clinical Research Study Group. Arch Intern Med 1998;158:1213-20.

43. Calhoun WJ, Lavins BJ, Minkwitz MC, Evans R, Gleich GJ, Cohn J. Effect of zafirlukast (Accolate) on cellular mediators of inflammation: bronchoalveolar lavage findings after segmental antigen challenge. Am J Respir Crit Care Med 1998;157:1381-9.

44. Leff JA, Pizzichini E, Efthimiadis A, et al. Effect of montelukast (MK-0476) on airway eosinophilic inflammation in mildly uncontrolled asthma: a randomized, placebo-controlled trial. Am J Respir Crit Care Med 1997;155:A977. (Abst)

45. Denburg JA, Wood L, Gauvreau G, Sehmi R, Inman MD, O'Byrne PM. Bone marrow contribution to eosinophilic inflammation. Mem Inst Oswaldo Cruz 1997;92:33-5.

46. Sehmi R, Wood LJ, Watson R, et al. Allergen-induced increases in IL-5 receptor-expression on bone marrow-derived CD $34^{+}$cells from asthmatic subjects. A novel marker of progenitor cell commitment towards eosinophilic differentiation. J Clin Invest 1997;100:2466-75.

47. Payan DG, Goodman DW, Goetzl EJ. Biochemical and cellular characterization of the regulation of human leukocyte function by lipoxygenase products of arachidonic acid. In: LW Charkin and DM Bailey, eds. The Leukotrienes: Chemistry and Biology. New York: Academic Press, 1984:231-45.

48. Moqbel R, Sass-Kuhn SP, Goetzl EJ, Kay AB. Enhancement of neutrophil- and eosinophil-mediated, complement-dependent killing of schistosomula of Schistosoma mansoni in vitro by leukotriene $\mathrm{B}_{4}$. Clin Exp Immunol 1983;52:519-27.

49. Shroeder JM, Kameyoshi Y, Christophers E. RANTES, a novel eosinophil chemotactic cytokine. Ann NY Acad Sci 1994;725:91-103.

50. Luster AD, Rothenberg ME, Role of the monocyte chemoattractant protein and eotaxin subfamily of chemokines in allergic inflammation. J Leukoc Biol 1997;62:620-33.

51. Humbert M, Ying S, Corrigan CJ, et al. Bronchial mucosal expression of the genes encoding chemokines RANTES and MCP-3 in symptomatic atopic and nonatopic asthmatics: relationship to the eosinophil-active cytokines interleukin (IL)-5, granulocyte macrophage-colony-stimulating factor and IL-3. Am J Respir Cell Mol Biol 1997;16:1-8.

52. Taha RA, Minshall EM, Miotto D, et al. Eotaxin and monocyte chemotactic protein-4 mRNA expression in small airways of asthmatic and nonasthmatic individuals. J Allergy Clin Immunol 1999;103:476-83.

53. Center DM, Kornfeld H, Cruikshank WW. Interleukin-16. Int J Biochem Cell Biol 1997;29:1231-4

54. Lim KG, Wan HC, Bozza PT, et al. Human eosinophils elaborate the lymphocyte chemoattractant, IL-16 (lymphocyte chemoattractant factor) and RANTES. J Immunol 1996;156:2566-70.

55. Laberge S, Ernst $\mathrm{P}$, Ghaffar O, et al. Increased expression of interleukin-16 in bronchial mucosa of subjects with atopic asthma. Am J Respir Cell Mol Biol 1997;17:193-202. 


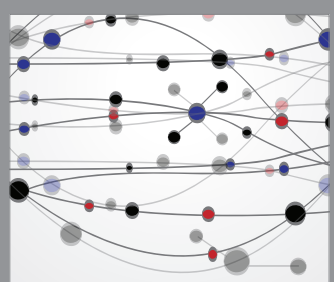

The Scientific World Journal
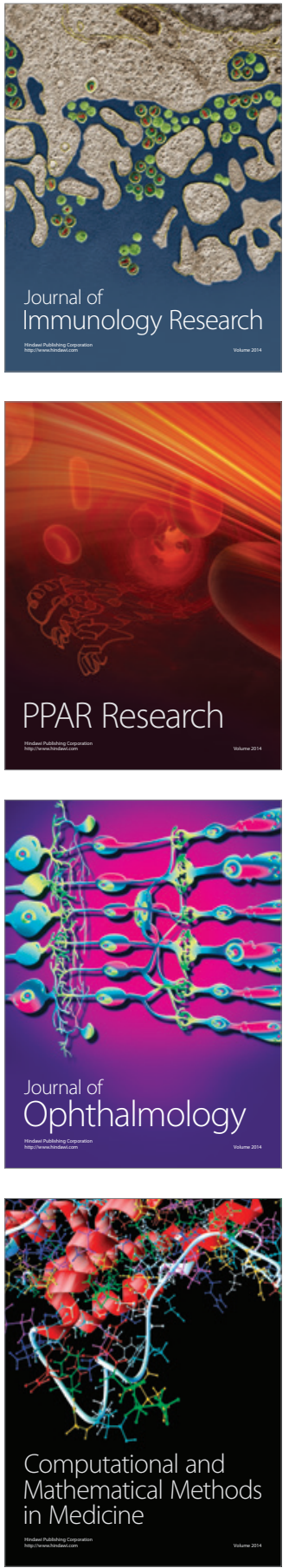

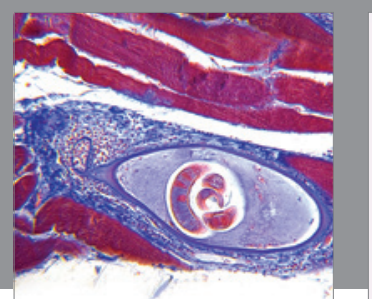

Gastroenterology Research and Practice

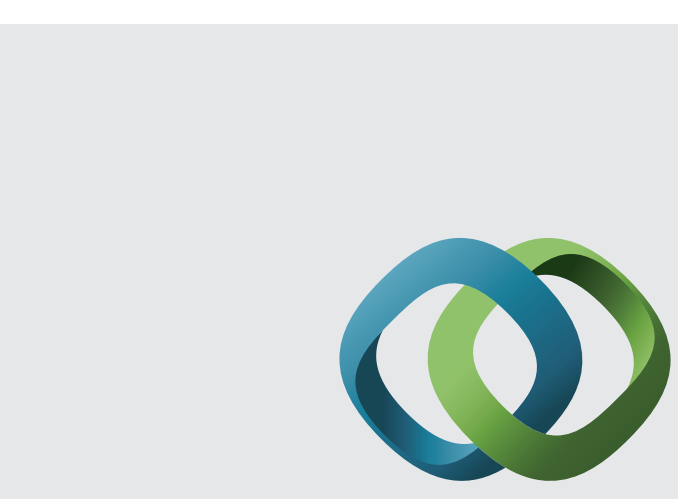

\section{Hindawi}

Submit your manuscripts at

http://www.hindawi.com
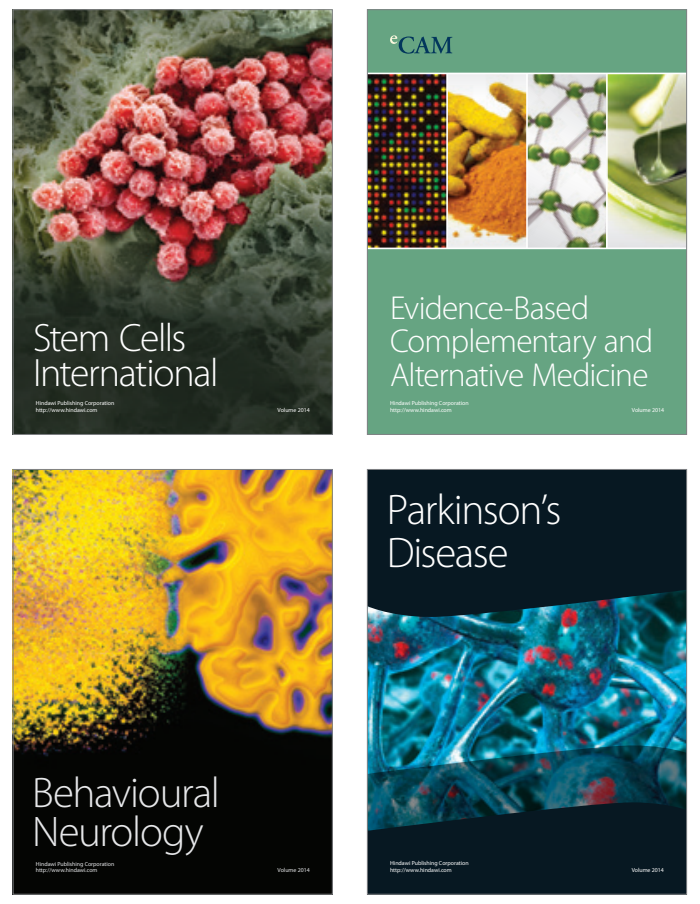
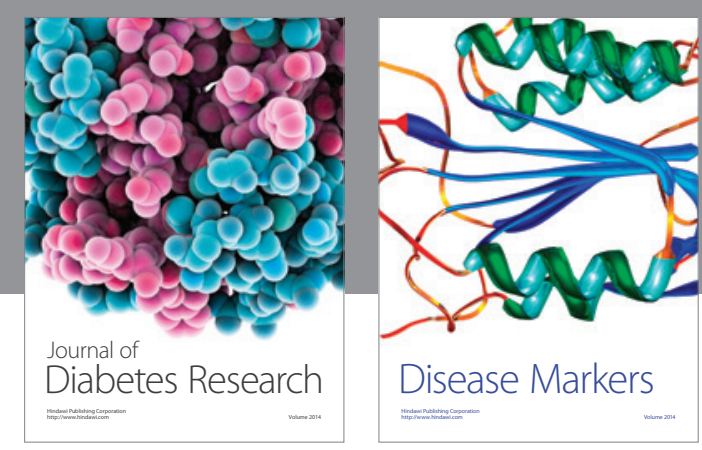

Disease Markers
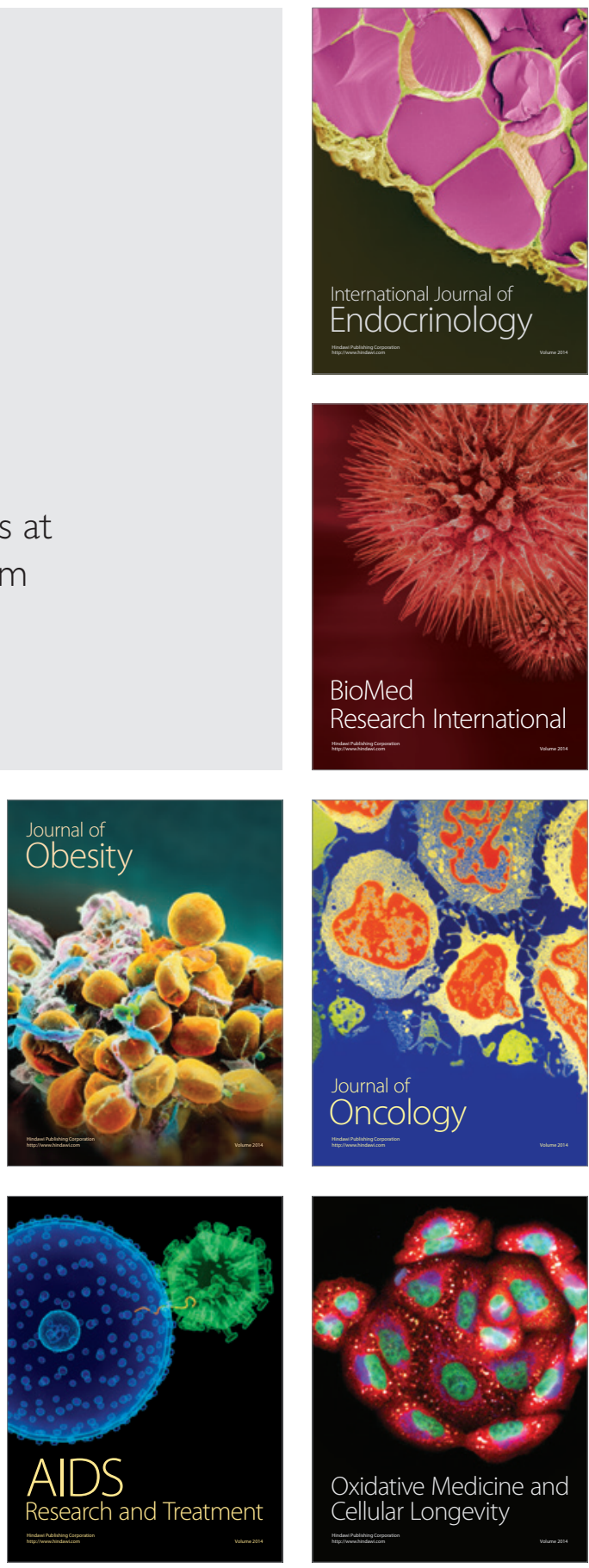